\title{
Effects of Addition of Swine Skin on the Technological Characteristics of Mortadella Produced in an Industrial Unit
}

\author{
Karem Muraro $^{\mathrm{a}}$, Jamile Zeni ${ }^{*}$, Rogério Luis Cansian ${ }^{\mathrm{a}}$, Juliana Steffens ${ }^{\mathrm{a}}$, \\ Eunice VAlduga ${ }^{\mathrm{a}}$, And GeCiane Toniazzo BACKes ${ }^{\mathrm{a}}$ \\ a Department of Food Engineering, URI - Erechim, Av.7 de Setembro, 1621, CEP 99709-910, Erechim - RS, \\ Brazil \\ ${ }^{*}$ Corresponding author \\ jamilezeni@uricer.edu.br \\ TEL.: +55-54-35209000
}

Received: 8 July 2020; Published online: 18 October 2021

\begin{abstract}
The aim of this work was to evaluate the effects of the addition of swine skin on the technological characteristics of mortadella formulations produced on industrial scale. The effects of concentrations of swine skin (1.5 to $5.5 \%$ ) and sodium chloride (2 to $3 \%$ ) on total protein, total fat, starch, moisture, water activity, sodium, $\mathrm{pH}$ and texture profile (hardness, adhesiveness, elasticity, cohesiveness and chewiness) were evaluated and compared to a mortadella formulation without swine skin addition. The mortadella formulations with addition of 3.5 to $5.5 \%$ swine skin and 2 to $2.5 \%$ sodium chloride are in accordance with Brazilian legislation and provided an increase of approximately $12 \%$ in protein content, a decrease of $14 \%$ in sodium content and a water activity less than 0.9488 . The swine skin and sodium chloride provided stability to the mortadella and influenced its texture, mainly in hardness, elasticity and chewiness.
\end{abstract}

Keywords: Emulsified product; Texture profile; Protein; Water activity

\section{Introduction}

Emulsified meat products, such as mortadella, are among the most widely produced. Their consumption has become popular mainly due to low cost, pleasant taste and variety of products available (Guerra et al., 2011), allowing access to those who are unable to consume the minimum amounts of daily protein (Shimokomaki \& Olivo, 2006). Because they are industrialized products, which diversify the use and consumption of meat and add value to less noble cuts, the materials used in production must be of a quality contributing to the action of additives and provide for an increase in shelf life without bringing any damage to health (Godfray et al., 2018).
Bologna-type sausages are widely consumed in many countries and are of great economic importance to the meat industry.

The production of mortadella is characterized by a specific procedure: meat is forced through a special mincing machine, named "exterminator", where a meat mixture is obtained that is not, however, an emulsion (Barbieri et al., 2013). A particularly long and intense cooking process allows the meat to develop its typical organoleptic characteristics and stabilizes the microbiota of the product, ensuring a long shelf life (Barbieri et al., 2013). They are made from beef, swine, chicken or meat mixtures, with addition of different ingredients and flavorings, including extenders or binders and fillers (Fernandez-Lopez 
et al., 2020; Muraoka Junior et al., 2019; Saldana, Siche, et al., 2018).

Brazilian legislation (Brazil, 2015a, 2015b) establishes some quality parameters, including maximum values of water activity (0.955) and sodium concentration (135 mg/100 g) for mortadella sold at room temperature $\left(22{ }^{\circ} \mathrm{C}\right)$. However, industries are finding it difficult to comply with these established values, thus it is necessary to evaluate alternatives for product preparation that guarantees safety for the consumer.

Swine skin is considered a by-product because it is abundant in slaughter animals, representing a very significant portion of the live animal's weight, in the order of 3.0 to $8.0 \%$ (Ockerman \& Hansen, 1994). On, average, $5.5 \mathrm{~kg}$ of skin can be removed from one swine carcass (Quevedo, 2005), corresponding to approximately $30 \%$ of the total protein, up to $81 \%(\mathrm{w} / \mathrm{w})$ of collagen (Reginato \& Teixeira, 2009) and about $30 \%$ of fat (Vidal et al., 2020). Fat plays an important role in the manufacturing process as well as in the final texture of mortadella (Saldana, Garcia, et al., 2018). Swine skin can be used to make meat products, such as gelatin and crackling (Ockerman \& Hansen, 1994), and it can also act as an emulsifying agent in the food industry (Nagai et al., 2015; Vidal et al., 2020), for example, as used in the manufacture of mortadella (Agostinho dos Santos Alves et al., 2016; Benelli et al., 2015). In this sense, the aim of this work was to evaluate the effects of the addition of swine skin, a by-product of the meat industry, on the technological characteristics of mortadella formulations produced on an industrial scale.

\section{Materials and Methods}

\subsection{Product formulation}

Mortadella formulations were developed in an industry, located in the western region of the State of Santa Catarina, Brazil. Mortadella formulations $(\mathrm{n}=3)$ with swine skin - X1 (1.5 to 5.5 $\% \mathrm{w} / \mathrm{w})$ and sodium chloride $-\mathrm{X}_{2}(2$ to $3 \%$ $\mathrm{w} / \mathrm{w})$ were prepared using a $2^{2}$ factorial design matrix (Table 1, run 1 to 7 ). The other ingredients of the formulations were fixed (undeclared quantities): water, swine meat, mechani- cally separated poultry meat (MSPM), swine fat and liver, cassava starch, soy protein and additives (sodium lactate, sodium tripolyphosphate, disodium pyrophosphate, sodium hexametaphosphate, sodium erythorbate, monosodium glutamate, mealybug carmine, sodium nitrite, dehydrated glucose and condiments: garlic, nutmeg and white pepper). The fixed operating conditions were mixing time $(30 \mathrm{~min})$, stirring speed $(60 \mathrm{rpm})$, raw materials temperature $\left(6^{\circ} \mathrm{C}\right.$ and $-12{ }^{\circ} \mathrm{C}$ ) and water temperature $\left(22^{\circ} \mathrm{C}\right)$. The levels were defined based on preliminary tests and in compliance with the technical regulation of quality and identity for mortadella (Brazil, 2000). One traditional mortadella formulation (Table 1, run 8) with no added swine skin $(\mathrm{n}=3)$ was also prepared in order to compare with the other formulations.

The raw materials were crushed in a grinder (Weiller model 1612, Brazil), with a particle size of approximately $8 \mathrm{~mm}$ and sent to the mixer (AMFEC model cbm6000, Condado de Norfolk). Then the crushed meat and the other ingredients were mixed for approximately $30 \mathrm{~min}$. The mass was placed under vacuum (Cozzini, VSP3000, USA), with a double vacuum pump to remove air bubbles, and then fed to an emulsion/reduction system (Cozzini, AR 901, USA) which had an output disc of $1.2 \mathrm{~mm}$ to refine and homogenize the mass. The mass was stuffed into polyethylene plastic, $0.13 \mathrm{~mm}$ thick, diameter of $72 \mathrm{~mm}$ and length of $290 \mathrm{~mm}$, with approximately $500 \mathrm{~g}$ per unit, and cooked in an oven (Maurer, KSC36A1, Germany) until the internal temperature reached $74{ }^{\circ} \mathrm{C}$, monitored by sensor (Maurer, Probe PT-100, Germany). Next, the mortadella was cooled at $25^{\circ} \mathrm{C} \pm 1^{\circ} \mathrm{C}$ until analysis was carried out. As dependent variables (responses) of the $2^{2}$ factorial design and the traditional formulation (without swine skin), the total protein, total fat, starch, moisture, water activity, sodium, $\mathrm{pH}$ and texture profile (hardness, adhesiveness, elasticity, cohesiveness and chewiness) were assessed.

\subsection{Analytical determinations}

The formulations were evaluated in relation to the total protein by method 981.10 (AOAC, 
Table 1: Factorial design matrix $2^{2}$ (coded and real values) and response in total protein, total fat, moisture, water activity $\left(\mathrm{a}_{w}\right)$, starch, sodium and $\mathrm{pH}$ of mortadella formulations.

\begin{tabular}{|c|c|c|c|c|c|c|c|c|c|}
\hline \multirow{2}{*}{ Run } & \multicolumn{2}{|c|}{$\begin{array}{l}\text { Independent } \\
\text { Variables* }\end{array}$} & \multirow{2}{*}{$\begin{array}{c}\text { Total } \\
\text { Protein } \\
(\%)\end{array}$} & \multirow{2}{*}{$\begin{array}{c}\text { Total } \\
\text { Fat } \\
(\%)\end{array}$} & \multirow[t]{2}{*}{$\begin{array}{l}\text { Moisture } \\
\text { (\%) }\end{array}$} & \multirow{2}{*}{$a_{W}$} & \multirow[t]{2}{*}{$\begin{array}{c}\text { Starch } \\
(\%)\end{array}$} & \multirow[t]{2}{*}{$\begin{array}{c}\text { Sodium } \\
(\mathrm{mg} / 100 \mathrm{~g})\end{array}$} & \multirow{2}{*}{$p H$} \\
\hline & $\boldsymbol{X}_{1}$ & $\boldsymbol{X}_{2}$ & & & & & & & \\
\hline 1 & $-1(1.5)$ & $-1(2.0)$ & $12.58^{d} \pm 0.021$ & $19.01^{e} \pm 0.021$ & $55.48^{b} \pm 0.030$ & $0.9567^{b} \pm 0.0001$ & $3.39^{b} \pm 0.015$ & $1134.4^{f} \pm 1.966$ & $6.67^{c} \pm 0.02$ \\
\hline 2 & $1(5.5)$ & $-1(2.0)$ & $13.69^{a} \pm 0.068$ & $19.72^{b} \pm 0.011$ & $54.01^{e} \pm 0.02$ & $0.9488^{c} \pm 0.0001$ & $3.59^{a} \pm 0.021$ & $1185.6^{e} \pm 1.120$ & $6.67^{a} \pm 0.01$ \\
\hline 3 & $-1(1.5)$ & $1(3.0)$ & $12.98^{c} \pm 0.023$ & $18.95^{f} \pm 0.100$ & $55.26^{c} \pm 0.035$ & $0.9415^{e} \pm 0.0001$ & $3.43^{b} \pm 0.011$ & $1458.0^{a} \pm 0.555$ & $6.69^{a} \pm 0.01$ \\
\hline 4 & $1(5.5)$ & $1(3.0)$ & $13.65^{a} \pm 0.404$ & $19.62^{c} \pm 0.017$ & $53.97^{e} \pm 0.021$ & $0.9401^{f} \pm 0.0006$ & $3.33^{b} \pm 0.021$ & $1440.5^{b} \pm 1.286$ & $6.70^{a} \pm 0.01$ \\
\hline $5,6,7^{* *}$ & $0(3.5)$ & $0(2.5)$ & $13.30^{b} \pm 0.003$ & $19.46^{d} \pm 0.011$ & $54.67^{d} \pm 0.011$ & $0.9474^{d} \pm 0.0007$ & $3.33^{b} \pm 0.002$ & $1199.0^{d} \pm 2.378$ & $6.68^{a} \pm 0.01$ \\
\hline $8^{* * *}$ & - & - & $12.04^{e} \pm 0.025$ & $22.17^{a} \pm 0.015$ & $58.12^{a} \pm 0.025$ & $0.9720^{a} \pm 0.0011$ & $3.08^{c} \pm 0.010$ & $1377.1^{c} \pm 0.888$ & $6.71^{b} \pm 0.01$ \\
\hline \multicolumn{10}{|c|}{$\begin{array}{l}{ }^{*} \mathrm{X}_{1}=\text { swine skin }(\%), \mathrm{X}_{2}=\text { sodium chloride }(\%) \text {. Fixed independent variables: water, swine meat, mechanically separated poultry meat (CMS), } \\
\text { pork fat (undeclared quantities; } \mathrm{n}=3) \text {. The fixed operating conditions were: mixing time }(30 \text { min), stirring speed }(60 \mathrm{RPM}) \text {, raw material } \\
\text { temperature }\left(6^{\circ} \mathrm{C} \text { and }-12^{\circ} \mathrm{C}\right) \text { and water }\left(22^{\circ} \mathrm{C}\right) \text {. Mean } \pm \text { standard deviation followed by equal letters in the same column do not differ } \\
\text { statistically in a level of } 5 \% \text { (Tukey's test). } \\
* * \text { Average of the central point. }\end{array}$} \\
\hline
\end{tabular}

2019d), moisture by method 985.26 (AOAC, 2019b), total fat by method 991.36 (AOAC, 2019e), sodium by method 976.25 (AOAC, 2019a) and pH by method 981.12 (AOAC, 2019c). Water activity $\left(\mathrm{a}_{w}\right)$ was determined using AquaLab (AquaLab model 4TE, USA). The texture profile (TPA) of mortadella $(\mathrm{n}=3)$ at room temperature $\left(22{ }^{\circ} \mathrm{C}\right)$ was obtained using cubes of $20 \mathrm{~mm}$ and a texturometer (Stable Micro Systems model TA. XT, England), with load cell of $10 \mathrm{~kg}$, flat-bottomed stainless steel cylindrical probe (diameter of $31.8 \mathrm{~mm}$ ), calibration distance of $55 \mathrm{~mm}$ from probe height, pre-test speed of $3 \mathrm{~mm} / \mathrm{s}$, test speed of $1 \mathrm{~mm} / \mathrm{s}$ and 3 $\mathrm{mm} / \mathrm{s}$, a maximum force required to compress the initial weight by $40 \%$ (the maximum force required to compress the initial weight was determined after experimental tests) and return time of $5 \mathrm{~s}$ (Harper et al., 2012).

\section{$2.3 \quad$ Statistical analysis}

The results $(\mathrm{n}=3)$ were statistically analyzed by analysis of variance, and then the means were compared via Tukey test using Statistic 7.0 software, with significance level of $95 \%$. Results were also analyzed by Pearson correlation and principal component analysis (PCA) using XLSTAT free software.

\section{Results and Discussion}

Table 1 shows the matrix of the $2^{2}$ factorial design with coded (real) values of independent variables, traditional formulation (run 8), and the responses of total protein $(\mathrm{TP})$, total fat $(\mathrm{TF})$, moisture $(\mathrm{M})$, water activity $\left(\mathrm{a}_{w}\right)$, starch $(\mathrm{S})$, sodium $\left(\mathrm{Na}^{+}\right)$and $\mathrm{pH}$ of mortadella formulations.

For protein, the maximum content was 13.69 $\mathrm{g} / 100 \mathrm{~g}$ (run 2), with $2 \%$ of sodium chloride and $5.5 \%$ of swine skin. However, the formulation with $3 \%$ of sodium chloride (runs 3 and 4), exceeds sodium values of $13.50 \mathrm{~g} / 100 \mathrm{~g}$ provided by ANVISA (Brazil, 2000). Swine skin, sodium chloride and the interaction of variables had a significant $(p<0.05)$ positive influence on protein content. All the runs presented protein content within the standard established by Normative Instruction $n^{o} 04$ of 2000 (Brazil, 2000). Equation 1 presents a first order coded model that describes total protein as a function of swine skin and sodium chloride concentrations, within the studied ranges. The model was validated by analysis of variance, with a correlation coefficient of 0.99 and $\mathrm{F}_{\text {calculated }} 7.36$ times greater than the tabulated $\mathrm{F}_{\text {value }}$, which enabled the construction of the contour curve (Fig. 1a), showing that there is an increase in total protein content (13.30 to $13.69 \%$ ) when the concentration of swine skin increases (3.5 to $5.5 \%$ ), corresponding to an increase of approximately $12 \%$ of protein when 

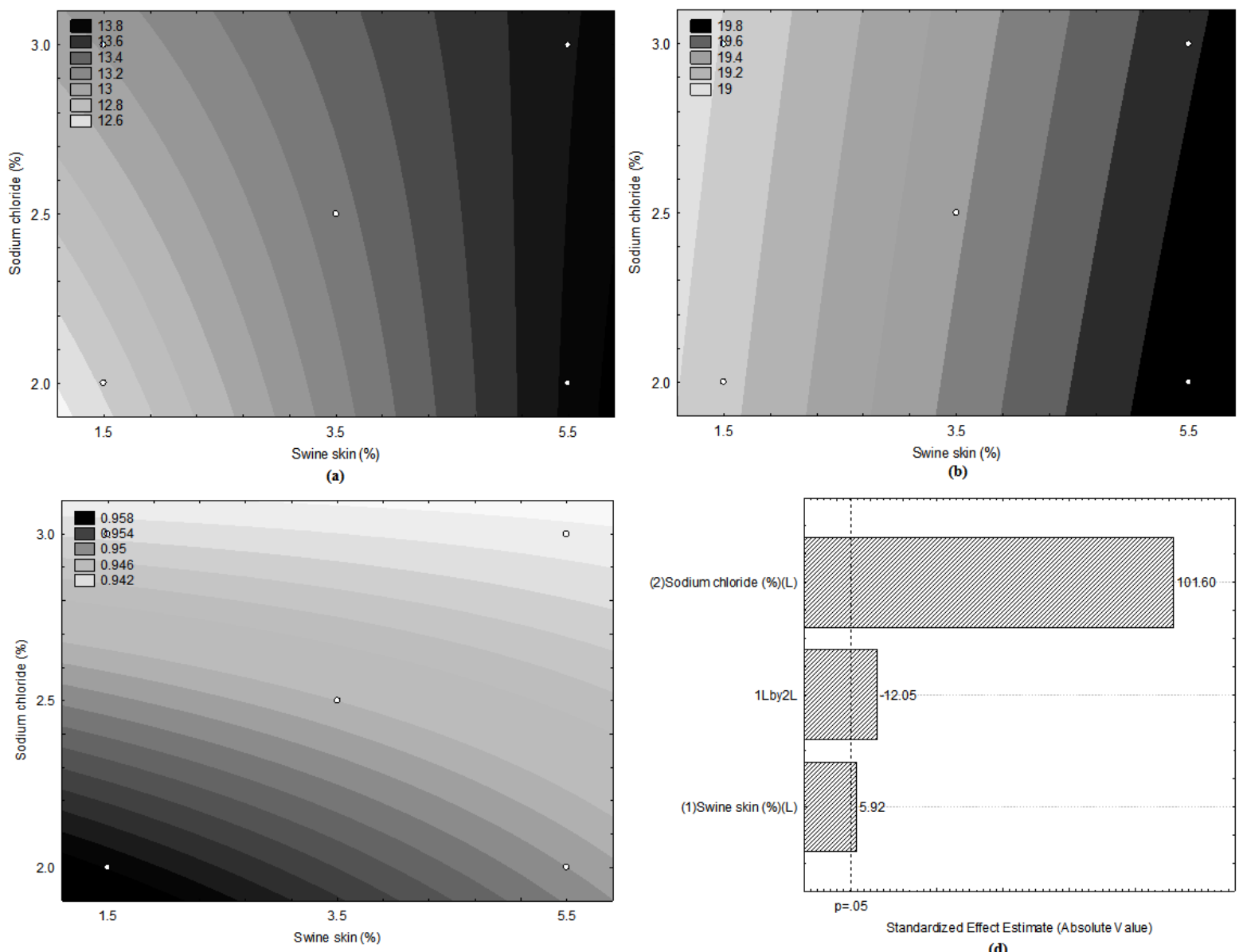

(d)

Figure 1: Contour curves as a function of swine skin and sodium chloride concentration for total protein content (\%) (a), total fat (\%) (b), water activity (c) and Pareto graph (d) with estimated effects (absolute value) of the variables tested for the sodium content of the mortadella formulations, respectively.

compared to the traditional mortadella formulation (Table 1). The values of the present study are higher than those reported by Benelli et al. (2015), which used $6.4 \%$ of swine skin in the preparation of mortadella and obtained $12.09 \%$ of protein.

The increase in protein content observed in the present study, even with addition of less swine skin, may be due to the influence of salt in the solubilization of myofibrillar proteins, responsible for increasing hydration and water retention capacity and stabilization of the meat batter, which reduces losses in the cooking process
(Agostinho dos Santos Alves et al., 2017; Bannwart et al., 2014).

$$
T P=13.26+0.445 X_{1}+0.090 X_{2}-0.108 X_{1} \cdot X_{2}
$$

Where $\mathrm{TP}=$ Total protein $(\%), \mathrm{X}_{1}=$ swine skin $(\%), \mathrm{X}_{2}=$ sodium chloride (\%). All formulations contained around $19 \%$ of total fat, which is far below the maximum allowed $(30 \%)$ by Brazilian legislation (Brazil, 2000). The maximum obtained was $19.72 \mathrm{~g} / 100 \mathrm{~g}$ on run 2 , with $2 \%$ of sodium chloride and $5.5 \%$ of swine skin. This study allowed a reduction of approximately $15 \%$ in fat content when compared to the traditional formulation (run 8), obtaining a healthier prod-

\begin{tabular}{l|l|l|l} 
IJFS & October 2021 & Volume 10 & pages 371-382
\end{tabular} 
Table 2: Factorial design matrix $2^{2}$ (coded and real values) and response in total protein, total fat, moisture, water activity $\left(\mathrm{a}_{w}\right)$, starch, sodium and $\mathrm{pH}$ of mortadella formulations.

\begin{tabular}{|c|c|c|c|c|c|c|c|}
\hline \multirow[b]{2}{*}{ Run } & \multicolumn{2}{|c|}{ Independent Variables* } & \multicolumn{5}{|c|}{ Texture profile } \\
\hline & $\boldsymbol{X}_{1}$ & $\boldsymbol{X}_{2}$ & $\begin{array}{l}\text { Hardness } \\
(N)\end{array}$ & $\begin{array}{c}\text { Adhesiveness } \\
\text { (N.s) }\end{array}$ & $\begin{array}{c}\text { Elasticity } \\
(\mathrm{mm})\end{array}$ & Cohesiveness & $\begin{array}{c}\text { Chewiness } \\
\text { (N.mm) }\end{array}$ \\
\hline 1 & $-1(1.5)$ & $-1(2.0)$ & $26.10^{b} \pm 0.527$ & $-5.79^{d} \pm 0.019$ & $1.66^{c} \pm 0.014$ & $0.842^{a} \pm 0.001$ & $395.14^{a} \pm 2.054$ \\
\hline 2 & $1(5.5)$ & $-1(2.0)$ & $28.64^{a} \pm 1.080$ & $-7.17^{c} \pm 0.326$ & $1.58^{c} \pm 0.035$ & $0.847^{a} \pm 0.006$ & $323.77^{a} \pm 2.249$ \\
\hline 3 & $-1(1.5)$ & $1(3.0)$ & $25.71^{e} \pm 0.774$ & $-3.83^{e} \pm 0.090$ & $1.64^{d} \pm 0.035$ & $0.840^{a} \pm 0.004$ & $312.97^{a} \pm 6.360$ \\
\hline 4 & $1(5.5)$ & $1(3.0)$ & $27.88^{b} \pm 0.407$ & $-9.66^{b} \pm 0.002$ & $1.69^{b} \pm 0.100$ & $0.847^{a} \pm 0.007$ & $398.89^{a} \pm 10.476$ \\
\hline $5 ; 6 ; 7^{* *}$ & $0(3.5)$ & $0(2.5)$ & $26.81^{c} \pm 0.535$ & $-5.85^{b} \pm 0.74$ & $1.64^{c} \pm 0.189$ & $0.834^{a} \pm 0.001$ & $390.27^{a} \pm 14.699$ \\
\hline $8 * * *$ & - & - & $24.09^{f} \pm 0.225$ & $-27.15^{a} \pm 0.232$ & $1.70^{a} \pm 0.013$ & $0.833^{a} \pm 0.001$ & $180.75^{b} \pm .544$ \\
\hline
\end{tabular}

$* \mathrm{X}_{1}=$ swine skin (\%), $\mathrm{X}_{2}=$ sodium chloride (\%). Fixed independent variables: water, swine meat, mechanically separated stirring speed $(60 \mathrm{rpm})$, raw material temperature. Mean \pm standard deviation followed by equal letters in the same column do not differ statistically in a level of $5 \%$ (Tukey's test).

uct with a lower fat content.

Equation 2 presents the first order coded model that describes total fat content as a function of the swine skin and sodium chloride concentration, within the studied ranges. The model was validated by analysis of variance, with a correlation coefficient of 0.97 and $\mathrm{F}_{\text {calculated }} 8.58$ times greater than the tabulated $\mathrm{F}_{\text {value }}$, which enabled the construction of the contour curve Fig. 1b demonstrating that the maximum total fat content is located in a region of maximum concentration of swine skin. Sodium chloride did not influence the total fat content.

$$
T F=19.38+0.347 X_{1}
$$

Where $\mathrm{TF}=$ Total fat $(\%), \mathrm{X}_{1}=$ swine skin (\%), $\mathrm{X}_{2}=$ sodium chloride $(\%)$. One important consideration is the relationship between the protein and total fat contents. In standard Bologna mortadella from Brazil (Brazil, 2015a) containing around $12 \%$ protein and $25 \%$ of total fat and the traditional mortadella formulation of the present study (Table 1, run 8) the protein/fat ratio is approximately 0.5 , and in the runs with swine skin (Table 1 , runs 1 to 7 ), it was about 0.7. The traditional mortadella formulation (Table 1, run 8) contained more fat when compared with runs 1 to 7 , a relative reduction of $12 \%$ of fat.

Furthermore, the addition of different concentrations of swine skin (1.5 to $5.5 \%$ ) and sodium chloride (2 to $3 \%$ ) promoted a reduction in the mortadella moisture. Run 4 (Table 1) with $5.5 \%$ of swine skin and $3 \%$ of sodium chloride had a moisture content of $53.97 \%$ compared to $58.12 \%$ for the traditional mortadella formulation.

The lowest value of water activity was 0.9401 (run 4, Table 1). As expected, the more salt that was added the lower the water activity, since water activity is directly related to salt concentration. Thus, as salt concentration increases, water activity decreases.

Swine skin, sodium chloride and the interaction of variables had a significant $(p<0.05)$ positive influence on water activity. Equation 3 presents the first order coded model that describes water activity as function of swine skin and sodium chloride, within the studied ranges. The model was validated by analysis of variance, with a correlation coefficient of 0.99 and $\mathrm{F}_{\text {calculated }} 33.43$ times greater than the value of the tabulated $\mathrm{F}_{\text {value, }}$ which enabled the construction of the contour curve shown in Fig. 1c, demonstrating that the minimum water activity content is found in a maximum range of sodium chloride. The swine skin provided an increase in protein content of mortadella and contributed to the reduction of water activity.

$$
a_{w}=0.947-0.002 X_{1}-0.006 X_{2}+0.002 X_{1} \cdot X_{2}
$$

Where $\mathrm{a}_{w}=$ water activity, $\mathrm{X}_{1}=$ swine skin (\%), $\mathrm{X}_{2}=$ sodium chloride (\%). Orsolin et al. (2015) studied $\mathrm{a}_{w}$ during the storage of bologna mortadella, and obtained values ranging from 0.969 


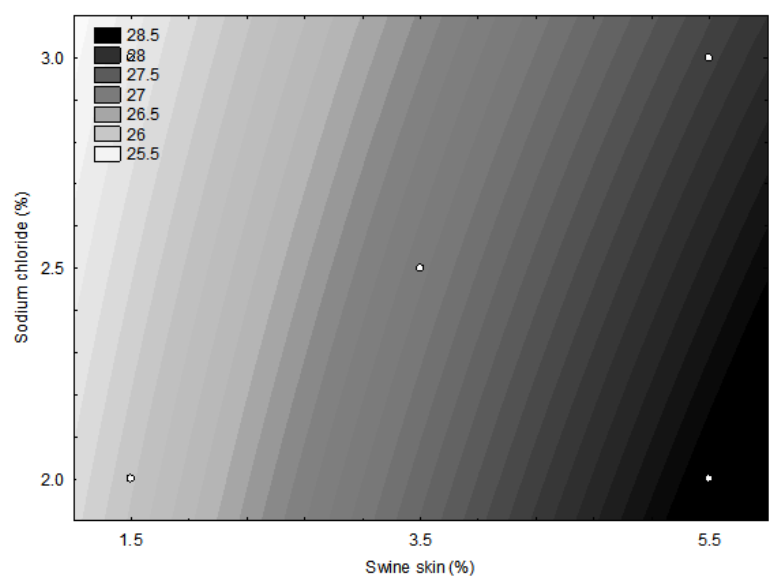

(a)

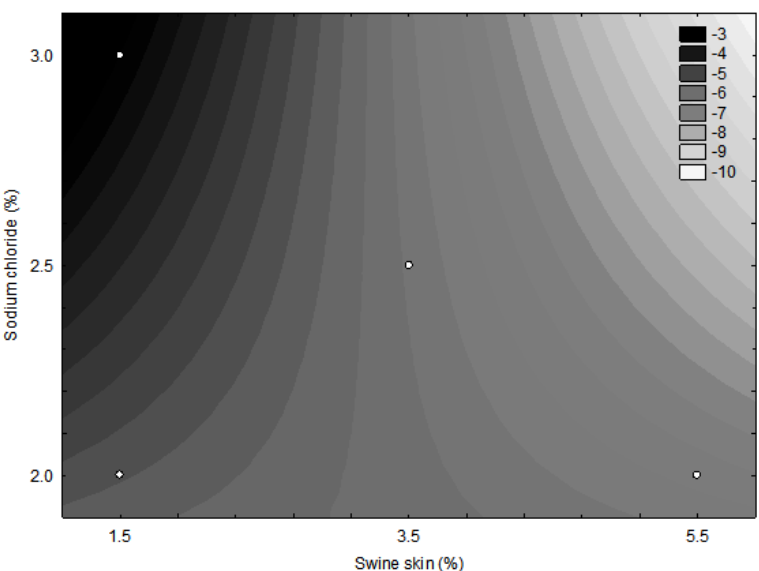

(b)

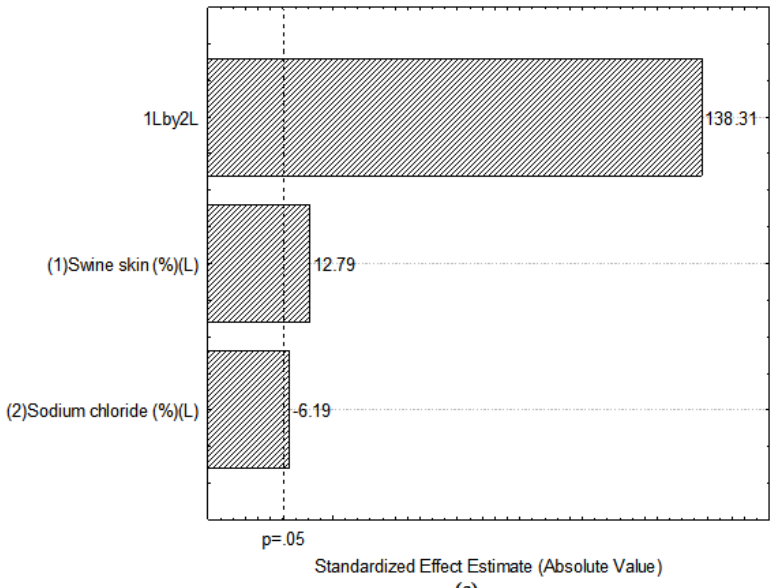

(c)

Figure 2: Contour curves as a function of the concentration of swine skin and sodium chloride for hardness (N) (a) adhesiveness (Ns) (b) and Pareto graph (c) with the estimated effects (absolute value) of the variables tested for the chewiness of mortadella formulations, respectively.

to 0.975 . Fiorda and de Siqueira (2009) studied mortadella with meat mechanically separated from poultry and swine, and found $\mathrm{a}_{w}$ values of 0.957 . It is noteworthy that the water activity values mentioned are higher than those found in the present study (Table 1 and Fig. 1c).

Starch content ranged from 3.08 to $3.59 \mathrm{~g} / 100$ $\mathrm{g}$ (Table 1), being in accordance with the current legislation (Brazil, 2000), and the swine skin and sodium chloride variables had no influence on this parameter.

The sodium content (Table 1) observed in all formulations varied from 1134.4 to $1458.0 \mathrm{mg} / 100$ $\mathrm{g}$, and is similar when compared with mortadella from the Brazilian market, which usually contain between 1063 and $1480 \mathrm{mg} / 100 \mathrm{~g}$ of sodium (Brazil, 2012; Martins et al., 2015).

Fig. 1d shows a Pareto graph with the estimated effects of variables in the $2^{2}$ factorial design for sodium content. The sodium chloride variable had a positive influence $(p<0.05)$, demonstrating that as sodium chloride content increases, sodium values in the formulations also increase. Formulations with $2 \%$ (runs 1 and 2) and $2.5 \%$ sodium chloride (runs 5, 6 and 7) present relative reductions of 17 to $13 \%$ in sodium content when 


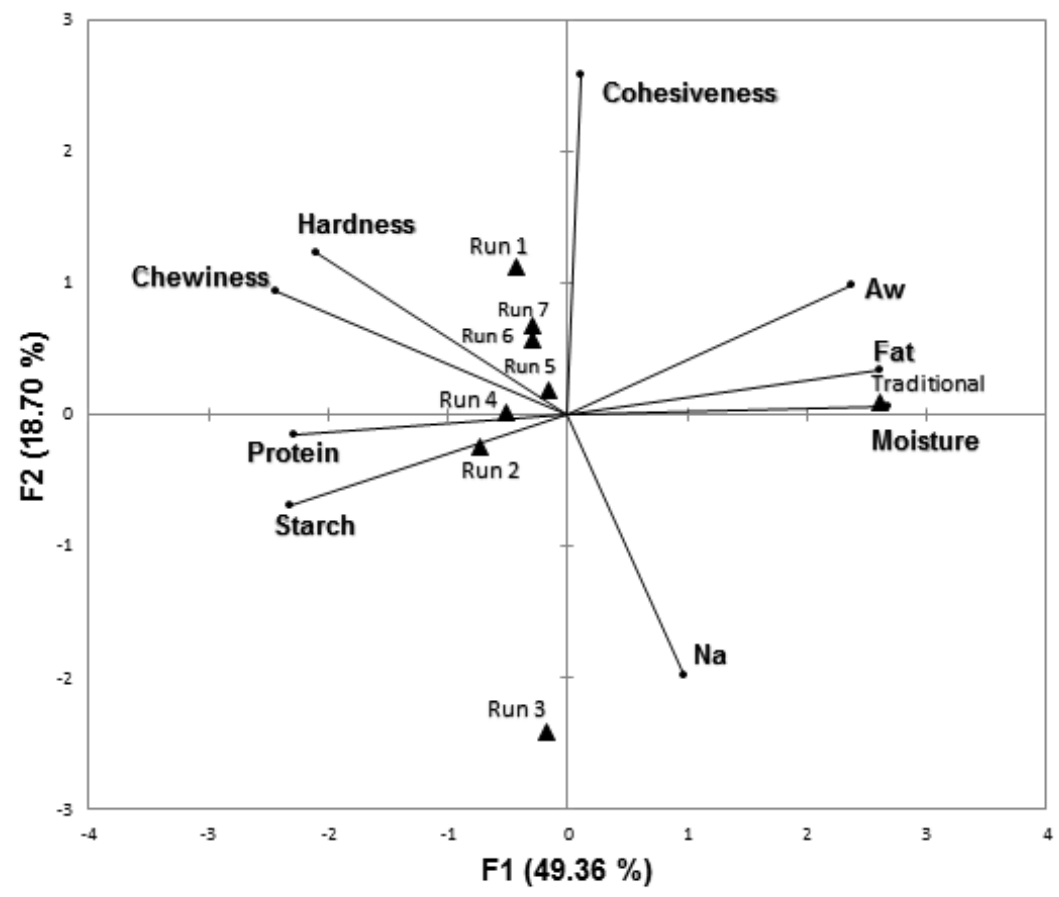

Figure 3: Principal Component Analysis (PCA) for the variables total protein, total fat, starch, moisture, water activity $\left(\mathrm{a}_{w}\right)$, sodium, $\mathrm{pH}$, hardness, adhesiveness, elasticity, cohesiveness and specific chewiness of mortadella formulations ( 7 planning tests complete factorial $2^{2}$ ).

compared to the traditional formulation (run 8). Sodium chloride is recognized as a multifunctional ingredient in meat products and is normally used at concentrations of 1.5 to $2.5 \%$ $(\mathrm{w} / \mathrm{w})$ to intensify flavor, inhibit microbes, extend the shelf life and solubilize myofibrillar proteins (Ordóñes et al., 2005).

The addition of sodium chloride and swine skin had no influence on $\mathrm{pH}$, with values of approximately 6.7 (Table 1). The $\mathrm{pH}$ values were considered acceptable for this type of meat product (Agostinho dos Santos Alves et al., 2017; Pietrasik \& Janz, 2010). According to Toldrá (2010), $\mathrm{a}_{w}$ less than 0.98 and $\mathrm{pH}$ around 6.00 are considered ideal for emulsified meat products so as to guarantee their microbial and structural stability.

Table 2 shows the matrix of the $2^{2}$ factorial design with the coded (real) values of the independent variables studied and the responses for the texture profile in terms of hardness, adhe- siveness, elasticity, cohesiveness and chewiness of mortadella formulations.

The swine skin and sodium chloride did not significantly influence elasticity and cohesiveness in runs 1 to 7 , however, the traditional mortadella formulation (run 8) showed greater elasticity. Sodium chloride and swine skin addition had no influence $(p>0.05)$ on elasticity and cohesiveness, with mean values of $1.64 \mathrm{~mm}$ and 0.83 , respectively (Table 2) which were similar to those of the traditional formulation (without addition of skin).

Hardness was influenced by the variables studied, with a highest mean value of $28.64 \mathrm{~N}(2.0$ $\%$ sodium chloride and $5.5 \%$ swine skin - run 2) compared with $24.09 \mathrm{~N}$ for the traditional formulation.

Equation 4 presents the first order coded model that describes hardness as a function of swine skin and sodium chloride, within the studied ranges. The model was validated by analysis 
of variance, with a correlation coefficient of 0.98 and $\mathrm{F}_{\text {calculated }} 10.21$ times higher than the tabulated $\mathrm{F}_{\text {value }}$, which enabled the construction of the contour curve shown in Fig. 2a, demonstrating that the maximum hardness is found in the highest concentrations of swine skin and lowest sodium chloride.

$$
H=26.97+1.18 X_{1}-0.287 X_{2}
$$

Where $\mathrm{H}=$ Hardness $(\mathrm{N}), \mathrm{X}_{1}=$ swine skin (\%), $\mathrm{X}_{2}=$ sodium chloride (\%). Swine skin and sodium chloride variables had a negative influence on adhesiveness, and the traditional formulation (without swine skin) had a significantly lower adhesiveness value $(p<0.05)$. Equation 5 presents the first order coded model that describes the adhesiveness as a function of swine skin and sodium chloride concentration variables, within the studied ranges. The model was validated by analysis of variance, with a correlation coefficient of 0.97 and $\mathrm{F}_{\text {calculated }} 1.87$ times greater than the tabulated $\mathrm{F}_{\text {value }}$, which enabled the construction of the contour curve shown in Fig. 2b, demonstrating that there is an increase in the adhesiveness parameter with low levels of swine skin and by increasing the levels of sodium chloride.

$$
A D=-6.28-1.80 X_{1}-0.134 X_{2}-1.11 X_{1} \cdot X_{2}
$$

Where $\mathrm{AD}=$ Adhesiveness (N.s), $\mathrm{X}_{1}=$ swine skin $(\%), \mathrm{X}_{2}=$ sodium chloride $(\%)$. Chewiness was positively influenced $(p<0.05)$ by the addition of swine skin and the interaction with sodium chloride (Fig. 2c), and the chewiness values were higher than those of the traditional formulation. According to (Saldana, Garcia, et al., 2018), instrumental texture properties of mortadella are affected by the fat level of the formulation. The reduction of fat promotes changes in the microstructure of mortadella, generating products with more disorganized structure.

Fig. 3 presents the Principal Component Analysis (PCA) for variables total protein, total fat, starch, moisture, water activity, sodium, $\mathrm{pH}$, hardness, adhesiveness, elasticity, cohesiveness and chewiness of mortadella formulations.

In Principal Component Analysis (PCA), variables are represented as vectors, which characterize the runs that are located close to them.
The longer the vector, the better the explanation of the variability between the characteristics evaluated. The first (F1) and second (F2) dimensions explained $68.06 \%$ of the total variance. The main component 1 (PC1) accounted for $49.36 \%$, while the main component 2 (PC2) accounted for $18.70 \%$.

The values obtained by means of Pearson's correlation (Table S1) confirmed the relationship between the variables observed in PCA, where fat showed a positive correlation with protein $(\mathrm{r}=$ $0.922)$ and cohesiveness $(r=0.645)$, and a negative correlation in relation to moisture $(\mathrm{r}=$ 0.907). Protein showed a negative correlation $(p<0.05)$ in relation to moisture $(\mathrm{r}=-0.946)$ and water activity $(\mathrm{r}=-0.556)$. A negative correlation of water activity in relation to sodium content $(\mathrm{r}=-0.870)$ and $\mathrm{pH}(\mathrm{r}=-0.734)$ was observed. Positive correlations between hardness and chewiness $(\mathrm{r}=0.627)$, cohesiveness and chewiness $(r=0.634)$, chewiness and elasticity $(\mathrm{r}=0.935)$ and chewiness and cohesiveness $(\mathrm{r}=$ $0.600)$ were also observed.

Collagen and fat in swine skin are complementary emulsifying agents, providing stability to the emulsified mass, and acting on texture, especially on hardness, adhesiveness and chewiness. In addition, they stabilize emulsions by binding water and fat, also assisting in the taste and preservation of the product, through the gelling of myosin (Benelli et al., 2015; Choe et al., 2013). The concentration of protein available for gelation is fundamental to the determination of rheological properties of the matrix formed during the processing of embedded meat, and determines the texture and stability of meat products (Sun \& Holley, 2011).

Swine skin, which contains collagen in its composition, increases the protein content and can also act as a complementary emulsifying agent to stabilise the emulsified mass (Ordóñes et al., 2005). Collagen protein is used in the food industry to improve elasticity, consistency and stability of food (Olivo \& Shimokomaki, 2002). The development of a new product, with addition of swine skin, achieved a nutritional improvement, mainly by increasing protein content. In addition, swine skin and sodium chloride contribute to the reduction of water activity in meat products thus preventing the risks of microbial growth (Dar \&

\begin{tabular}{l|l|l|l} 
IJFS & October 2021 & Volume 10 & pages 371-382
\end{tabular} 
Light, 2014). During cooking, there is a partial unfolding of protein structure which is accelerated by increasing temperature $\left(>65\right.$ to $70{ }^{\circ} \mathrm{C}$ ) and cooking time. As a result, there is an aggregation of the unfolded regions of the protein and formation of a three-dimensional network that prevents coalescence of fat globules (Tornberg, 2005; Visessanguan et al., 2000).

Water retention by the protein structure is favored in the presence of chloride ions. Chloride affects cooking performance, and the juiciness and softness of the product. Chloride ions are much more important than sodium ions for achieving an increased water binding by meat proteins as well as accelerating the formation of color in cured products and increasing the reaction rate of nitrite to nitric oxide. Water activity is significantly reduced with the addition of salt, favoring microbial inhibition and a longer shelf life. Sodium ions are responsible for the characteristic flavor and for intensifying flavors (Devine \& Jensen, 2004; Ordóñes et al., 2005; Sebranek, 2009).

\section{Conclusion}

Mortadella with a high concentration of swine skin $(3.5$ to $5.5 \%)$ tends to have a high protein and fat content, approximately 13.7 and 19.7 $\%$, respectively. These parameters are negatively correlated, mainly with moisture and water activity. The collagen present in swine skin gives stability to the product, influencing its texture, mainly with regard to hardness, cohesiveness and chewiness.

Swine skin is considered a by-product of high protein content which is abundant in the meat products industry. The collagen present in swine skin can be used as an alternative emulsifying agent in the manufacture of emulsified products to add value and increase the protein nutritional value, as well as reducing the cost of production.

\section{Acknowledgements}

This study was financed in part by the National Council for Scientific and Technological Development - Brazil (CNPq), Coordination for the Improvement of Higher Education Personnel -
Brazil (CAPES) - Finance Code 001 and Research Support Foundation of the State of Rio Grande of Sul - Brazil (FAPERGS).

\section{References}

Agostinho dos Santos Alves, L. A., Manuel Lorenzo, J., Alvarenga Goncalves, C. A., dos Santos, B. A., Heck, R. T., Cichoski, A. J., \& Bastianello Campagnol, P. C. (2016). Production of healthier bologna type sausages using pork skin and green banana flour as a fat replacers. Meat Science, 121, 73-78. https://doi.org/10. 1016/j.meatsci.2016.06.001

Agostinho dos Santos Alves, L. A., Manuel Lorenzo, J., Alvarenga Goncalves, C. A., dos Santos, B. A., Heck, R. T., Cichoski, A. J., \& Bastianello Campagnol, P. C. (2017). Impact of lysine and liquid smoke as flavor enhancers on the quality of low-fat bologna-type sausages with $50 \%$ replacement of nacl by kcl. Meat Science, 123, 50-56. https://doi.org/ 10.1016/j.meatsci.2016.09.001

AOAC. (2019a). Association of official analytical chemists. official method 976.25. determination of sodium. official methods of the aoac international, 21th ed. maryland/usa: Aoac.

AOAC. (2019b). Association of official analytical chemists. official method 981.10. determination of protein. official methods of the aoac international, 21th ed. maryland/usa: Aoac.

AOAC. (2019c). Association of official analytical chemists. official method 981.12. determination of ph. official methods of the aoac international, 21th ed. maryland/usa: Aoac.

AOAC. (2019d). Association of official analytical chemists. official method 985.26. determination of moisture. official methods of the aoac international, 21th ed. maryland/usa: Aoac.

AOAC. (2019e). Association of official analytical chemists. official method 991.36. determination of fat. official methods of 
the aoac international, 21th ed. maryland/usa: Aoac.

Bannwart, G. C. M. d. C., Silva, M. E. M. P., \& Vidal, G. (2014). Redução de sódio em alimentos: Panorama atual e impactos tecnológicos, sensoriais e de saúde pública. Nutrire Rev. Soc. Bras. Aliment. Nutr, 348-365.

Barbieri, G., Bergamaschi, M., Barbieri, G., \& Franceschini, M. (2013). Survey of the chemical, physical, and sensory characteristics of currently produced mortadella bologna. Meat Science, 94(3), 336-340. https : / / doi .org / 10.1016/j. meatsci.2013.02.007

Benelli, J., Toniazzo, G., Prestes, R. C., \& Tres, M., V. (2015). Development and utilization of pork skin emulsion in mortadella as a soy protein substitute. International Food Research Journal, 22(5), 2126-2132.

Brazil. (2000). Ministry of Agriculture, Livestock and Supply. Normative Instruction № 4 of March 31, 2000. Brasília, Brazil. Institutes Technical Regulation of Mechanically Separated Meat Identity and Quality, Mortadella, fresh sausage and Sausage. http://www.lex.com.br/doc_ 20302_INSTRUCAO_NORMATIVA_N_ 4_DE_31_DE_MARCO_DE_2000.aspx

Brazil. (2012). National Health Surveillance Agency. Technical report № 50/2012. Sodium content in processed foods. http: / / portal . anvisa . gov . br / resultado de- busca ? p_p_id $=101 \&$ p_p_lifecycle $=$ $0 \&$ p_p_state $=$ maximized $\&$ p_p_mode $=$ view \& p_p_col_id $=$ column $-1 \&$ p_ p_col_count $=1 \&$ \& 101_struts_action $=$ /asset_publisher / view_content \& _101_ assetEntryId $=2977113 \&$ \& 101_type $=$ content \& _101_groupId $=33916 \&$ \& 101 _ urlTitle $=$ informe - tecnico - n - 50 - de 2012\&inheritRedirect $=$ true

Brazil. (2015a). Ministry of Agriculture, Livestock and Supply. Circular Office № 005/2015/CGI/DIPOA/SDA July 27, 2015. Information on registration of mortadella product kept at room temperature. https : / / www . cnabrasil . org . br / assets / arquivos / Of \% C3 \%
ADcio - Circular - 11_2015 - CGI_DIPOA_ _SDA-Rotulagem_Bovinos_Registro-deprodutos-com-indicacao-raca.pdf

Brazil. (2015b). Ministry of Agriculture, Livestock and Supply. Circular Office $\mathrm{N}^{\mathrm{Q}} \quad 006 / 2015 / \mathrm{CGI} / \mathrm{DIPOA} / \mathrm{SDA}$ Agosto 6, 2015. Adita Circular Office $\mathrm{N}^{\underline{0}}$ 005/2015/CGI/DIPOA/SDA. https : / / www . cnabrasil . org . br / assets / arquivos / Of \% C3 \% ADcio Circular - 11_2015 - CGI_DIPOA_SDA Rotulagem_Bovinos_Registro - de produtos-com-indicacao-raca.pdf

Choe, J.-H., Kim, H.-Y., Lee, J.-M., Kim, Y.-J., \& Kim, C.-J. (2013). Quality of frankfurter-type sausages with added pig skin and wheat fiber mixture as fat replacers. Meat Science, 93(4), 849-854. https://doi.org/10.1016/j.meatsci.2012. 11.054

Dar, Y. L., \& Light, J. M. (2014). Food texture design and optimization. John Wiley \& Sons.

Devine, C., \& Jensen, W. K. (2004). Encyclopedia of meat sciences. Academic Press.

Fernandez-Lopez, J., Lucas-Gonzalez, R., Viuda-Martos, M., Sayas-Barbera, E., Ballester-Sanchez, J., Haros, C. M., Martinez-Mayoral, A., \& Perez-Alvarez, J. A. (2020). Chemical and technological properties of bologna-type sausages with added black quinoa wet-milling coproducts as binder replacer. Food Chemistry, 310. https:// doi.org/10. 1016/j.foodchem.2019.125936

Fiorda, F. A., \& de Siqueira, M. I. D. (2009). Avaliação do ph e atividade de àgua em produtos cárneos. Revista EVS-Revista de Ciências Ambientais e Saúde, 36(4), 817-826.

Godfray, H. C. J., Aveyard, P., Garnett, T., Hall, J. W., Key, T. J., Lorimer, J., Pierrehumbert, R. T., Scarborough, P., Springmann, M., \& Jebb, S. A. (2018). Meat consumption, health, and the environment. Science, 361(6399). https://doi. org/10.1126/science.aam5324

Guerra, I. C. D., Felex, S. S. S., Meireles, B. R. L. M., Dalmas, P. S., Moreira, R. T., Honorio, V. G., Morgano, 
M. A., Milani, R. F., Benevides, S. D., Queiroga, R. C. R. E., \& Madruga, M. S. (2011). Evaluation of goat mortadella prepared with different levels of fat and goat meat from discarded animals [10th International Conference on Goats - Technological Development and Associate Attempts to a Sustainable Small Livestock Activity, Fed Rural Univ Pernambuco, Recife, BRAZIL, SEP 19-23, 2010]. Small Ruminant Research, 98(1-3, SI), 59-63. https://doi. org/10.1016/j.smallrumres.2011.03.019

Harper, B. A., Barbut, S., Lim, L. T., \& Marcone, M. F. (2012). Microstructural and textural investigation of various manufactured collagen sausage casings. Food Research International, 49(1), 494-500. https://doi.org/10.1016/j.foodres.2012. 07.043

Martins, A. P. B., Andrade, G. C., \& Bandoni, D. H. (2015). Avaliação do monitoramento do teor de sódio em alimentos: Uma análise comparativa com as metas de redução voluntárias no brasil. Vigilância sanitária em debate, 3(2), 564.

Muraoka Junior, M., de Oliveira, T. P., Goncalves, O. H., Leimann, F. V., Medeiros Marques, L. L., Barros Fuchs, R. H., Reitz Cardoso, F. A., \& Droval, A. A. (2019). Substitution of synthetic antioxidant by curcumin microcrystals in mortadella formulations. Food Chemistry, 300. https://doi.org/10.1016/j. foodchem.2019.125231

Nagai, T., Tanoue, Y., Kai, N., \& Suzuki, N. (2015). Characterization of collagen from emu (dromaius novaehollandiae) skins. Journal of Food Science and Technology - Mysore, 52(4), 2344-2351. https: / / doi.org / 10.1007/s13197-0141266-1

Ockerman, H. W., \& Hansen, C. L. (1994). Industrialización de subproductos de origen animal. Acribia Zaragoza.

Olivo, R., \& Shimokomaki, M. (2002). Carnes: No caminho da pesquisa. Imprint.

Ordóñes, J., Rodriguez, M. I. C., Sanz, M. L. G., Minguillón, G. D. G. F., Perales, L. H.,
\& Cortecero, M. D. S. (2005). Tecnologia de alimentos: Alimentos de origem animal. Porto Alegre: Artmed, 2, 41.

Orsolin, D., Steffens, C., Rosa, C. D., \& Steffens, J. (2015). Reduction of mortadella cooking time and evaluation of the final product quality. Ciência Animal Brasileira, $16(4), 589-597$.

Pietrasik, Z., \& Janz, J. A. M. (2010). Utilization of pea flour, starch-rich and fiberrich fractions in low fat bologna. Food Research International, 43(2, SI), 602608. https://doi.org/10.1016/j.foodres. 2009.07.017

Quevedo, A. (2005). Gelatina de suino. Avicultura Industrial, Redação SI-185.

Reginato, E., \& Teixeira, M. L. (2009). Evaluation of the biotechnological potential of bacteria of the gender Bacillus in the degradation of residues of skin of swine in the industry of foods. Revista Brasileira de Produtos Agroindustriais, $11(1), 81-86$.

Saldana, E., Garcia, A. d. O., Selani, M. M., Haguiwara, M. M. H., de Almeida, M. A., Siche, R., \& Contreras-Castillo, C. J. (2018). A sensometric approach to the development of mortadella with healthier fats. Meat Science, 137, 176190. https://doi.org/10.1016/j.meatsci. 2017.11.027

Saldana, E., Siche, R., da Silva Pinto, J. S., de Almeida, M. A., Selani, M. M., RiosMera, J., \& Contreras-Castillo, C. J. (2018). Optimization of lipid profile and hardness of low-fat mortadella following a sequential strategy of experimental design. Journal of Food Science and Technology - Mysore, 55(2), 811-820. https: //doi.org/10.1007/s13197-017-3006-9

Sebranek, J. G. (2009). Basic curing ingredients. Ingredients in meat products (pp. 1-23). Springer.

Shimokomaki, M., \& Olivo, R. (2006). Suplementação de vitamina e melhora a qualidade de carnes e derivados. Atualidades em ciência e tecnologia de carnes. São Paulo: Varela, 115-121.

Sun, X. D., \& Holley, R. A. (2011). Factors influencing gel formation by myofibrillar 
proteins in muscle foods. Comprehensive Reviews in Food Science and Food Safety, 10(1), 33-51. https://doi.org/ 10.1111/j.1541-4337.2010.00137.x

Toldrá, F. (2010). Handbook of meat processing. John Wiley \& Sons.

Tornberg, E. (2005). Effects of heat on meat proteins - implications on structure and quality of meat products [50th International Congress of Meat Science and Technology, Helsinki, FINLAND, AUG 08-13, 2004]. Meat Science, $70(3, \mathrm{SI})$, 493-508. https:// doi.org/10.1016/j. meatsci.2004.11.021

Vidal, A. R., Duarte, L. P., Schmidt, M. M., Cansian, R. L., Fernandes, I. A., de Oliveira Mello, R., Demiate, I. M., \& Dornelles, R. C. P. (2020). Extraction and characterization of collagen from sheep slaughter by-products. Waste Management, 102, 838-846. https://doi.org/10.1016/ j.wasman.2019.12.004

Visessanguan, W., Ogawa, M., Nakai, S., \& An, H. (2000). Physicochemical changes and mechanism of heat-induced gelation of arrowtooth flounder myosin. Journal of Agricultural and Food Chemistry, 48(4), 1016-1023. 